\title{
Response of Pseudoperonospora cubensis to Preventative Fungicide Applications Varies by State and Year
}

\author{
Anthony P. Keinath, ${ }^{1,+}$ Sally A. Miller, ${ }^{2}$ and Christine D. Smart ${ }^{3}$ \\ ${ }^{1}$ Coastal Research and Education Center, Clemson University, Charleston, SC 29414 \\ ${ }^{2}$ Department of Plant Pathology, The Ohio State University, Wooster, OH 44691 \\ ${ }^{3}$ School of Integrative Plant Science, Plant Pathology and Plant-Microbe Biology Section, Cornell University, Geneva, NY 14456
}

Accepted for publication 29 May 2019.

\section{Abstract}

In bioassays on cucumber (Cucumis sativus) in New York, Ohio, and South Carolina in 2015 and 2017, mandipropamid (Revus) and azoxystrobin (Quadris) failed to suppress downy mildew caused by Pseudoperonospora cubensis. Propamocarb (Previcur Flex), cymoxanil + famoxadone (Tanos), and fluopicolide (Presidio) were ineffective in one or two states in both years. Famoxadone, dimethomorph (Forum), cymoxanil
(Curzate), and mancozeb (Manzate) were ineffective in one state one year. Oxathiapiprolin, cyazofamid (Ranman), and fluazinam (Omega) suppressed downy mildew in $\geq 80 \%$ of the bioassays.

Keywords: fungicide resistance, vegetables, cucurbit, downy mildew
Cucurbit downy mildew caused by the oomycete Pseudoperonospora cubensis (Berk. \& M.A. Curtis) Rostovzev is a widespread, destructive cucurbit disease in the eastern and Midwestern United States and other temperate and tropical regions of the world. Resistance is available only in recently released, partially resistant cultivars of pickling and slicing cucumber (Cucumis sativus L.) (Adams and Quesada-Ocampo 2017; Brzozowski et al. 2016; McGrath et al. 2018). Thus, fungicides remain the primary method to manage downy mildew and prevent yield loss in cucumber, muskmelon, and other cucurbit crops (Adams and Quesada-Ocampo 2014, 2017; Hausbeck and Linderman 2014; Holmes et al. 2015; Keinath et al. 2003; Ojiambo et al. 2010; Wyenandt et al. 2017).

Insensitivity to fungicides in $P$. cubensis is a major challenge to managing downy mildew. Insensitivity to mefenoxam, quinone outside inhibitor (QoI) fungicides, and carboxylic acid amide fungicides was widespread in the United States by 2007 (Olaya et al. 2009). Prior to 2009, fluopicolide and propamocarb were ranked the first and second most effective fungicides, respectively, against downy mildew (Ojiambo et al. 2010). Recently, however, insensitivity to both active ingredients was verified in vitro with isolates collected between 2008 and 2014 in California, Florida, Georgia, Illinois, Maryland, Michigan, and North Carolina (Thomas et al. 2018). Seven of the 31 isolates assayed were

${ }^{\dagger}$ Corresponding author: A. P. Keinath; E-mail: tknth@clemson.edu

Funding: This material is based upon work supported, in part, by the National Institute of Food and Agriculture, U.S. Department of Agriculture, under project numbers NY-76829 and SC-1700536, and state and federal funds appropriated to The Ohio State University, Ohio Agricultural Research and Development Center; Cornell AgriTech, New York State Agricultural Experiment Station; and the Clemson University Experiment Station.

The author(s) declare no conflict of interest.

(C) 2019 The American Phytopathological Society insensitive to both fungicides. All seven doubly insensitive isolates were recovered from cucumber. Eighteen additional isolates were insensitive to fluopicolide. The study by Thomas et al. (2018) confirmed the lack of efficacy observed with fluopicolide in field fungicide trials done in many locations in the eastern United States (Adams and Quesada-Ocampo 2014; Hausbeck and Linderman 2014; Langston and Sanders 2013). In 2017, efficacy of propamocarb on pickling cucumber was very poor in Pennsylvania, where percentage control was <22\% (Gugino and Grove 2018).

A potted plant bioassay was developed originally to assess the response of cucurbit powdery mildew to fungicide applications (McGrath and Shishkoff 2001). This bioassay also has been used successfully to assess the response of $P$. cubensis to preventative fungicide applications (Baysal-Gurel et al. 2015; Keinath 2016; McGrath and Sexton 2018). In the downy mildew bioassay, potted cucumber plants are treated with fungicides and exposed to natural inoculum of $P$. cubensis. Statistical comparisons of disease severity ratings on fungicide-treated plants and the water-treated, nofungicide control treatment provide a rapid assessment of the response to fungicides applied preventatively (i.e., before infection). The bioassay, which can be completed within 4 weeks, inclusive of growing the plants, often provides the opportunity to include more fungicides than could be tested in field plots. No variation was observed among bioassays done simultaneously in three locations in northern Ohio (Baysal-Gurel et al. 2015). On the other hand, variation in results has been reported between bioassays done within a week of each other at the same location (Keinath 2016). The objective of this study was to compare the response of cucurbit downy mildew to preventative applications of fungicides across years and locations to determine the level of variation observed.

\section{Cucurbit Downy Mildew Fungicide Bioassays}

Six bioassays were conducted, one per year in 2015 and 2017 in New York, Ohio, and South Carolina (Table 1). Cucumber 'Straight 
Eight,' susceptible to both the A1 and A2 mating types of $P$. cubensis, was used. Each bioassay was set up in a randomized, complete block design with four replications, one pot per replication. Greenhouse-grown cucumber plants with at least three fully expanded leaves were transplanted into $10 \times 10-\mathrm{cm}$ square pots. One plant per pot was used in New York and Ohio, and two plants per pot were used in South Carolina. Plants were sprayed just until run-off with one test fungicide or water (Table 2). Fungicides were applied based on the highest labeled rate mixed in 468 liters/ha of water, a typical volume of water used by cucurbit growers (BaysalGurel et al. 2015). Technical-grade zoxamide (98.1\%) and famoxadone (97.8\%) (Corteva Agriscience, Midland, MI) were dissolved in 2.0 and $1.0 \mathrm{ml}$ of acetone, respectively, before mixing with $200 \mathrm{ml}$ of water.

One day after treatment, potted cucumbers were placed in the field by replication adjacent to Straight Eight cucumber plants grown as part of the sentinel plot network of the Cucurbit Downy Mildew Forecasting Center (Ojiambo et al. 2019). Field-grown cucumbers at each location had symptoms and signs of downy mildew owing to infection by naturally occurring populations of $P$. cubensis (Table 1). Bioassay plants were exposed to natural inoculum in the field for $48 \mathrm{~h}$ and then moved indoors to allow symptoms to develop. In New York, plants were placed in a greenhouse with temperature set for $25^{\circ} \mathrm{C}$ and a 14-h light regime. In Ohio, plants were placed in a greenhouse with temperature set at $24^{\circ} \mathrm{C}$ during the day and $22^{\circ} \mathrm{C}$ at night without supplemental lighting. In South Carolina, plants were placed in a growth chamber held at $21^{\circ} \mathrm{C}$ during the 12 -h lighted period and at $18^{\circ} \mathrm{C}$ during the dark period (Arauz et al. 2010). Relative humidity was set at $50 \%$ so that moisture did not condense on leaves, which prevented production of sporangia. Two nontreated cucumber plants placed in the chamber remained symptomless in each bioassay, evidence that there was no plant-to-plant spread in the chamber.

Downy mildew severity on each plant was rated on a scale of 0 to $100 \%$ in $5 \%$ increments plus $1 \%$ for trace amounts of disease 7 days after plants were placed into the greenhouse or growth chamber, which was 9 days after the beginning of the exposure period. Severity relative to the water control treatment, designated relative disease severity (RDS), was calculated by dividing the percentage severity rating for plants treated with each fungicide by the percentage severity for plants in the water control in the same replication (Keinath 2016; Thomas et al. 2018). RDS was used instead of disease severity to reduce variability owing to differences in disease pressure among locations or between years. Square-roottransformed RDS values were analyzed with maximum likelihood analysis of variance with the Gaussian response distribution (SAS PROC GLIMMIX, SAS version 9.4, SAS, Cary, NC). Year, state, and fungicide were considered fixed effects, and replication, nested within year or state, was considered a random effect. A separate analysis was used to compare RDS among states within years and between years within states. In this analysis, the water control treatment was excluded from the dataset to reduce inequality of variances among treatments.

\begin{tabular}{|c|c|c|}
\hline \multicolumn{3}{|c|}{$\begin{array}{c}\text { TABLE } 2 \\
\text { Fungicides tested for efficacy against cucurbit downy } \\
\text { mildew with a cucumber bioassay in two or three states }\end{array}$} \\
\hline Active ingredient(s) & Fungicide & $\begin{array}{l}\text { Field rate } \\
\text { (kg a.i./ha) }\end{array}$ \\
\hline $\begin{array}{r}\text { Ametoctradin } 26.9 \%+ \\
\text { dimethomorph } 20.2 \%\end{array}$ & Zampro 525SC & $0.31+0.23$ \\
\hline Azoxystrobin $22.9 \%$ & Quadris $2.08 \mathrm{~F}$ & 0.28 \\
\hline Chlorothalonil 54\% & Bravo Weather Stik 6F & 1.68 \\
\hline Cyazofamid $23.3 \%$ & Ranman 400SC & 0.08 \\
\hline $\begin{array}{l}\text { Cymoxanil } 25 \%+ \\
\text { famoxadone } 25 \%\end{array}$ & Tanos 50DF & $0.14+0.14$ \\
\hline Cymoxanil $60 \%$ & Curzate 60DF & 0.21 \\
\hline Dimethomorph $43.5 \%$ & Forum 4.16SC & 0.23 \\
\hline Fluazinam $40 \%$ & Omega 500F & 0.87 \\
\hline Fluopicolide $39.5 \%$ & Presidio 4SC & 0.14 \\
\hline $\begin{array}{c}\text { Mancozeb } 66.7 \%+ \\
\text { zoxamide } 8.3 \%\end{array}$ & Gavel 75DF & $1.49+0.19$ \\
\hline Mancozeb $75 \%$ & Manzate Pro-Stik 75DG & 1.68 \\
\hline Mandipropamid 23.3\% & Revus 2.08SC & 0.15 \\
\hline Oxathiapiprolin $10.2 \%$ & Orondis Opti A & 0.035 \\
\hline Propamocarb $66.5 \%$ & Previcur Flex 6SL & 1.01 \\
\hline Famoxadone & Technical grade & $0.14^{\mathrm{z}}$ \\
\hline Zoxamide & Technical grade & $0.19^{\mathrm{z}}$ \\
\hline
\end{tabular}

${ }^{y}$ Maximum rate given on fungicide label for downy mildew on cucurbit crop group; a.i. = active ingredient.

${ }^{\mathrm{z}}$ Famoxadone and zoxamide were applied at rates equivalent to the rates in the combination products Tanos and Gavel, respectively.

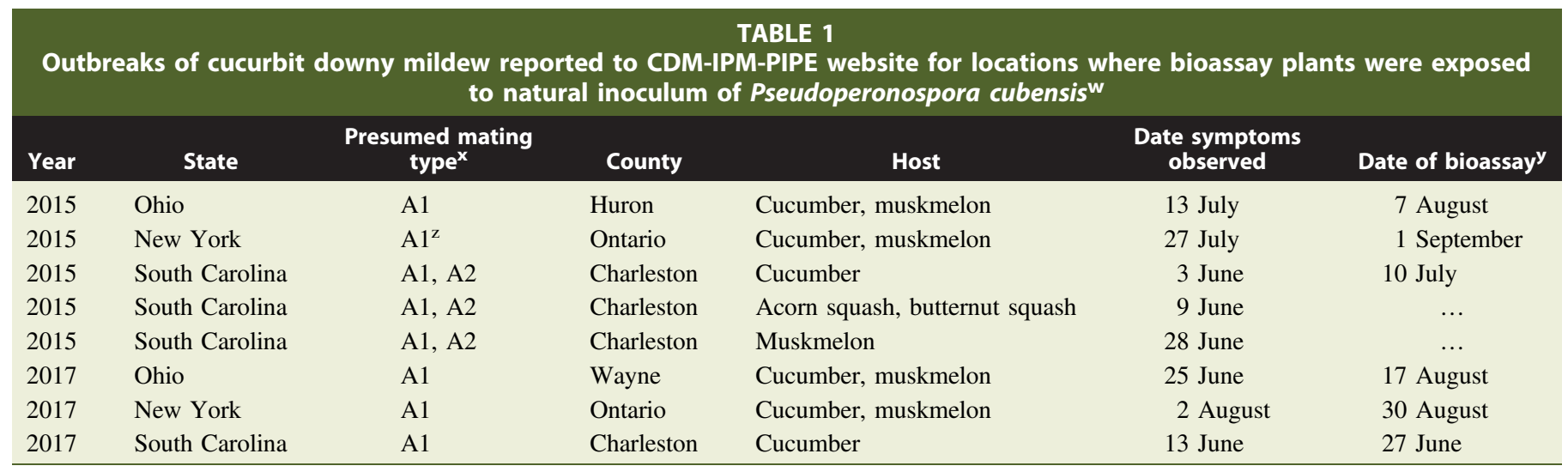

${ }^{\mathrm{w}}$ Ojiambo et al. (2019).

${ }^{\mathrm{x}}$ Mating type of $P$. cubensis at location inferred from symptoms on differential hosts (Thomas et al. 2017a, 2017b, 2017c). Lack of symptoms on watermelon or squash implies mating type A1.

${ }^{y}$ Date bioassay plants placed outdoors.

${ }^{\mathrm{z}}$ Genetic lineage II, as determined with a real-time PCR assay (Summers et al. 2015). 
In 2015 in New York, an isolate of P. cubensis from source cucumber plants was characterized as belonging to lineage II based on reaction with real-time PCR primers (Summers et al. 2015; Thomas et al. 2017a). In other locations where bioassay plants were exposed to natural inoculum of $P$. cubensis, the predominant lineage (I or II) and mating type (A2 or A1) were based on symptoms on differential cucurbit hosts (Thomas et al. 2017b, 2017c). Isolates belonging to lineage II (mating type A1) were present in all six bioassay locations. Isolates belonging to lineage I (mating type A2) were present in South Carolina in 2015, based on symptoms on Cucurbita spp. (Table 1).

Disease severity on the water control plants ranged from 56 to 99\% in five of the bioassays and was 15\% in Ohio in 2015 (data not shown). Across all analyses, RDS values $<3$ were not significantly different from 0 ( $t$ tests, $P \geq 0.10$ ) and indicated a negligible level of disease development. RDS values $>50$ were not significantly different from the water control treatment $(P>0.10)$ and indicated poor efficacy or a lack of efficacy. Based on RDS, suppression of downy mildew on cucumber was ineffective in at least one bioassay with 10 of 14 fungicides tested in 2015 and nine of 16 fungicides tested in 2017 (Table 3). Mandipropamid and azoxystrobin were ineffective in every bioassay in which they were included, as previously reported (Keinath 2016; McGrath and Sexton 2018; Olaya et al. 2009). Dimethomorph also was ineffective in both bioassays in which it was included. Propamocarb, cymoxanil + famoxadone, and fluopicolide were ineffective in one or two states in both years. Cymoxanil, famoxadone, and mancozeb were ineffective in one state one year. Zoxamide + mancozeb, zoxamide, fluazinam, and oxathiapiprolin significantly reduced RDS in every bioassay in which they were included $(P=0.01)$.

In both years, fluopicolide was ineffective in South Carolina but reduced RDS in New York and Ohio. Fluopicolide was ineffective in previous bioassays in Ohio and South Carolina (Baysal-Gurel et al. 2015; Keinath 2016) (Table 3). Propamocarb was ineffective in New York in 2015 and in Ohio in 2015 and 2017 but reduced
RDS in South Carolina in both years. Results with propamocarb do not match previous bioassay results, in which propamocarb reduced disease severity in Ohio in 2014 but not in South Carolina in the same year (Baysal-Gurel et al. 2015; Keinath 2016). Two isolates of $P$. cubensis collected in Ohio in 2013 and 2014, one of which was the A1 mating type, previously were determined to be insensitive to fluopicolide (Thomas et al. 2018). Three isolates from South Carolina, collected between 2012 and 2015, two of which were the A2 mating type, were sensitive to fluopicolide and propamocarb, as was one A1 isolate from New York. Thirty of the 31 isolates characterized by Thomas et al. (2018) for insensitivity to fluopicolide and propamocarb were collected prior to 2015. It is possible that the frequency of mating type A1 isolates insensitive to propamocarb increased during or after the 2015 growing season, based on bioassay results in Ohio and Upstate New York in this study and on Long Island New York (McGrath and Sexton 2018).

Thomas et al. (2018) used an RDS of 0.35 as the threshold between sensitivity and insensitivity and designated 20 and seven isolates of $P$. cubensis as insensitive to fluopicolide and propamocarb, respectively. Most of these isolates, 18 insensitive to fluopicolide and six insensitive to propamocarb, also would be considered insensitive with the threshold of 0.50 RDS used in this study and a previous study (Keinath 2016). However, the single isolate of the A2 mating type that was designated insensitive to fluopicolide by Thomas et al. (2018) had an RDS of 0.39, which would not be considered insensitive in the current study. All five A2 isolates tested by Thomas et al. (2018) were sensitive to propamocarb. Thus, propamocarb could be used to manage downy mildew on squash or watermelon, because these cucurbits are infected primarily by the A2 mating type (Thomas et al. 2017c).

The response of $P$. cubensis to applications of cymoxanil, famoxadone, or cymoxanil + famoxadone varied among the bioassays. Cymoxanil + famoxadone was ineffective in New York in 2015 and in South Carolina in 2015 and 2017. Cymoxanil + famoxadone

\begin{tabular}{|c|c|c|c|c|c|c|c|c|c|}
\hline & Cor & parisons amon & states and & $\begin{array}{l}\text { etween year } \\
\text { in a }\end{array}$ & $\begin{array}{r}\text { TABLE } 3 \\
\text { s of relative } d \\
\text { bioassay on c }\end{array}$ & $\begin{array}{l}\text { lowny mildew s } \\
\text { ucumber }\end{array}$ & everity value & fungicides & tested \\
\hline Year & State & Mandipropamid & Azoxystrobin & Fluopicolide & Propamocarb & Cymoxanil & $\begin{array}{l}\text { Cymoxanil + } \\
\text { famoxadone }\end{array}$ & Famoxadone & Chlorothalonil \\
\hline 2015 & NY & $84.8 \mathrm{~b}$ & $74.2 \mathrm{a}$ & $17.1 \mathrm{~b}$ & $91.2 \mathrm{a}$ & $1.0 \mathrm{~b}$ & $64.8 \mathrm{a}$ & ND & $9.4 \mathrm{~b}$ \\
\hline 2015 & $\mathrm{OH}$ & $179.8 \mathrm{a}$ & $98.9 \mathrm{a}$ & $39.6 \mathrm{~b}$ & $108.9 \mathrm{a}$ & $8.9 \mathrm{~b}$ & $3.9 \mathrm{~b}$ & ND & $48.1 \mathrm{a}$ \\
\hline 2017 & $\mathrm{OH}$ & $78.8 \mathrm{~A}^{*}$ & $69.7 \mathrm{~A}$ & $46.4 \mathrm{~A}$ & $71.4 \mathrm{~A}$ & $65.6 \mathrm{~A}^{*}$ & $37.0 \mathrm{~B} *$ & ND & $40.4 \mathrm{~A}$ \\
\hline 2017 & $\mathrm{SC}$ & $112.6 \mathrm{~A}$ & $121.5 \mathrm{~A}$ & $78.1 \mathrm{~A}$ & $3.0 \mathrm{~B} *$ & $43.5 \mathrm{~A}$ & $96.8 \mathrm{~A}$ & $37.6 \mathrm{~B}$ & $6.9 \mathrm{~B}$ \\
\hline Year & State & Mancozeb & $\begin{array}{c}\text { Mancozeb + } \\
\text { zoxamide }\end{array}$ & Zoxamide & Cyazofamid & Dimethomorph & $\begin{array}{l}\text { Ametoctradin + } \\
\text { dimethomorph }\end{array}$ & Fluazinam & Oxathiapiprolin \\
\hline 2015 & NY & $9.4 \mathrm{a}$ & $14.6 \mathrm{a}$ & ND & $0.0 \mathrm{~b}$ & ND & ND & $2.7 \mathrm{a}$ & ND \\
\hline 2017 & $\mathrm{SC}$ & $32.0 \mathrm{~B}$ & $24.3 \mathrm{~A}$ & $39.6 \mathrm{~A}$ & $2.5 \mathrm{AB}$ & $56.0 \mathrm{~A}$ & $44.0 \mathrm{~A}$ & $10.2 \mathrm{~A}$ & $\mathrm{ND}$ \\
\hline
\end{tabular}

${ }^{\mathrm{z}}$ Relative disease severity values $<3$ were not significantly different from $0, t$ tests, $P \geq 0.10$, and indicate a negligible level of disease development. Relative disease severity values $>50$ were not significantly different from the water control treatment, $P>0.10$, and indicate a lack of efficacy. State means by year within a column followed by the same lowercase (2015) or uppercase (2017) letter are not significantly different, Fisher's protected LSD, $P=0.03 ; 2017$ means followed by an asterisk differ significantly from 2015 means within fungicide columns, Fisher's protected least significant difference, $P<0.04$. 
also was ineffective previously in South Carolina in 2014 (Keinath 2016). Cymoxanil reduced RDS relative to the water control in New York and South Carolina, although the RDS for cymoxanil was significantly greater in South Carolina than in New York in both years (Table 3). Cymoxanil was ineffective in Ohio in 2017 in this study and on Long Island New York in 2017 (McGrath and Sexton 2018). The concentration of cymoxanil in Tanos, which is cymoxanil (300 $\mathrm{mg} / \mathrm{liter})+$ famoxadone is less than in Curzate $(450 \mathrm{mg} / \mathrm{liter})$. It may be more likely that the combination product is ineffective rather than cymoxanil alone. Famoxadone, which is not available as a separate formulated fungicide, was tested at the concentration it is present in cymoxanil + famoxadone. Insensitivity to azoxystrobin, a methoxy-acrylate in Fungicide Resistance Action Committee (FRAC) code 11, was widespread in this and other studies (Keinath 2016; Olaya et al. 2009). Insensitivity to famoxadone, an oxazolidinedione also in FRAC code 11, was observed only in New York, one of the two locations where it was tested in 2017. Although cross-resistance is assumed to occur among all QoI fungicides with FRAC code 11, P. cubensis may be slightly more sensitive to famoxadone than to azoxystrobin.

RDS values after treatment with mancozeb + zoxamide or mancozeb did not differ from each other in five of the six bioassays. In Ohio in 2017, however, RDS for mancozeb was significantly greater than RDS for mancozeb + zoxamide. In the two bioassays that included zoxamide alone, RDS after application of mancozeb + zoxamide, mancozeb, or zoxamide did not differ. However, mancozeb + zoxamide was among the most effective fungicides in three bioassays, whereas mancozeb was included in this group only once.

When RDS for a given fungicide differed between years in a state, the difference usually resulted because the fungicide reduced RDS compared with the water control in one year but not in the other year (Table 3). The year-by-fungicide interaction also was significant $(P=0.01)$ for the South Carolina dataset, because RDS for propamocarb was greater in 2015 than in $2017(P=0.007)$. In Ohio, the RDS in 2015 for mandipropamid was greater than 100, the value for the water control. The 2015 RDS was greater than the 2017 RDS $(P \leq 0.008)$. RDS for chlorothalonil was higher in Ohio than in New York or South Carolina in both years (Table 3).

Based on RDS for the nine fungicides tested in all states both years, fungicide response patterns in Ohio and New York matched each other seven times. Patterns in Ohio and South Carolina also matched seven times. Patterns in New York and South Carolina matched 11 times (Table 3). Fungicide response patterns were not related to the distances between bioassay locations. The lack of spatial correlation of results is not surprising, given the longdistance dispersal of sporangia of $P$. cubensis (Neufeld et al. 2018; Ojiambo and Holmes 2011). In a previous population genetics analysis, $P$. cubensis from Ohio differed genetically from populations in New York and South Carolina, but populations in New York and South Carolina did not differ from each other (Quesada-Ocampo et al. 2012).

\section{Conclusions}

As of 2017, isolates insensitive to fluopicolide or propamocarb were distributed unevenly within the eastern and Midwestern United States. A similar uneven distribution may exist for isolates with reduced sensitivity to cymoxanil and famoxadone. A conservative approach to recommending fungicides to manage cucurbit downy mildew avoids fungicides for which insensitivity has been found anywhere, because long-distance movement of fungicideinsensitive isolates is possible. Recommending fungicides for which insensitivity has been documented may put growers at risk of

yield loss, particularly with cucumber, which is very susceptible to mating type A1 (Adams and Quesada-Ocampo 2017; McGrath et al. 2018). Continued use of fungicides to which isolates of $P$. cubensis are insensitive is predicted to increase the proportion of the population that is insensitive (van den Bosch et al. 2014). The conservative approach, however, limits the number of active ingredients recommended. Selection pressure for insensitivity could increase for frequently applied fungicides (Brent and Hollomon 2007).

The bioassay is useful for determining the potential success of a preventative application of a large number of fungicides for suppressing initial infection by downy mildew. It offers the opportunity to make location- and cucurbit-specific fungicide recommendations. Seven of the 16 fungicide active ingredients tested in this study were among the most effective fungicides in at least two bioassays (Table 4). Based on RDS, oxathiapiprolin and fluazinam suppressed initial infection in $100 \%$ of the two and five bioassays in which they were included, respectively. Cyazofamid and zoxamide + mancozeb suppressed initial infection in five and four of six bioassays, respectively. The other three fungicides significantly reduced RDS in 33 to $50 \%$ of the bioassays in which they were included. Among them, several fungicides reduced RDS in one state in both years: chlorothalonil in South Carolina, cymoxanil in New York, and zoxamide + mancozeb in Ohio (Table 4). Although the bioassay results are a "snapshot" taken at a single location at a particular time, the results can be communicated to growers more rapidly than the results of season-long fungicide evaluations done in research plots. Successful management of cucurbit downy mildew requires multiple fungicide applications and rotations among fungicide active ingredients. Applications made later in the season can be based on in-field efficacy or preliminary results from concurrent research trials. Currently, the authors are part of a multistate project to assess fungicide efficacy against both mating types of $P$. cubensis in different regions of the eastern and Midwestern United States.

\section{TABLE 4}

Fungicides ranked among the most effective fungicides at suppressing initial infection by Pseudoperonospora cubensis in six cucumber bioassays ${ }^{z}$

2015

Fungicide

Chlorothalonil (Bravo)

Cyazofamid (Ranman)

Cymoxanil (Curzate)

Cymoxanil + famoxadone (Tanos)

Fluazinam (Omega)

Mancozeb + zoxamide (Gavel)

Oxathiapiprolin

${ }^{\mathrm{z}} \mathrm{E}=$ fungicide was effective; relative disease severity (RDS) on treated cucumber plants was significantly lower than on plants treated with water but significantly higher than on plants treated with the fungicide with the lowest RDS in the same bioassay, based on Fisher's protected least significant difference, $P \leq 0.01$. I = fungicide was ineffective (i.e., RDS on treated plants was not significantly different than on plants treated with water). $V=$ fungicide was highly effective (i.e., RDS not significantly different from RDS on fungicide-treated plants with the lowest RDS in the same bioassay). * = fungicide with the lowest RDS in the bioassay. $\mathrm{ND}=$ not done. 


\section{Acknowledgments}

We thank Holly Lange, Margaret Moodispaw, Claudio Vrisman, Virginia DuBose, and Casey Conrad for technical assistance. Technical contribution number 6754 of the Clemson University Experiment Station.

\section{Literature Cited}

Adams, M. L., and Quesada-Ocampo, L. M. 2014. Evaluation of fungicides for control of downy mildew on cucumber, Kinston 2013. Plant Dis. Manage. Rep. 8:V2401. Online publication. doi:10.1094/PDMR08.

Adams, M. L., and Quesada-Ocampo, L. M. 2017. Evaluation of fungicides for control of downy mildew on cucumber, Kinston 2016. Plant Dis. Manage. Rep. 11:V097. Online publication. doi:10.1094/PDMR11.

Arauz, L. F., Neufeld, K. N., Lloyd, A. L., and Ojiambo, P. S. 2010. Quantitative models for germination and infection of Pseudoperonospora cubensis in response to temperature and duration of leaf wetness. Phytopathology 100: 959-967.

Baysal-Gurel, F., Mera, J. R., and Miller, S. A. 2015. Monitoring Pseudoperonospora cubensis sensitivity to fungicides, 2014. Plant Dis. Manage. Rep. 9:V051. Online publication. doi:10.1094/PDMR09.

Brent, K. J., and Hollomon, D. W. 2007. Fungicide resistance in crop pathogens: How can it be managed? FRAC Monograph No. 1, 2nd ed. Fungicide Resistance Action Committee, Croplife International. www.frac.info/ publications/downloads

Brzozowski, L., Holdsworth, W. L., and Mazourek, M. 2016. 'DMR-NY401': A new downy mildew-resistant slicing cucumber. HortScience 51:1294-1296.

Gugino, B. K., and Grove, T. L. 2018. Evaluation of select fungicides and fungicide programs for managing downy mildew of cucumber. Plant Dis. Manage. Rep. R12:V035. Online publication. doi:10.1094/PDMR12.

Hausbeck, M. K., and Linderman, S. D. 2014. Evaluation of fungicides for control of downy mildew of cucumber, 2013. Plant Dis. Manag. Rep. 8:V304. Online publication. doi:10.1094/PDMR08.

Holmes, G. J., Ojiambo, P. S., Hausbeck, M. K., Quesada-Ocampo, L., and Keinath, A. P. 2015. Resurgence of cucurbit downy mildew in the United States: A watershed event for research and extension. Plant Dis. 99: 428-441.

Keinath, A. P. 2016. Utility of a cucumber plant bioassay to assess fungicide sensitivity in Pseudoperonospora cubensis. Plant Dis. 100:490-499.

Keinath, A. P., DuBose, V. B., Cantrell, J. P., and May, W. H., III. 2003. Comparison of protectant and systemic fungicides to control downy mildew on muskmelon. Fungicide Nematic. Tests 58:V047.

Langston, Jr., D. B., and Sanders, F. H. 2013. Evaluation of fungicides for control of downy mildew on cucumber in Georgia I, 2012. Plant Dis. Manage. Rep. 7:V108. Online publication. doi:10.1094/PDMR07.

McGrath, M. T., Menasha, S. R., and Sexton, Z. F. 2018. Evaluation of cucumber cultivars resistant to downy mildew, 2017. Plant Dis. Manage. Rep. 12:V069. Online publication. doi:10.1094/PDMR12.
McGrath, M. T., and Sexton, Z. F. 2018. Fungicide sensitivity of cucurbit downy mildew pathogen population on Long Island, NY, determined with seedling bioassay, 2017. Plant Dis. Manage. Rep. 12:V152. Online publication. doi: 10.1094/PDMR12.

McGrath, M. T., and Shishkoff, N. 2001. Resistance to triadimefon and benomyl: Dynamics and impact on managing cucurbit powdery mildew. Plant Dis. 85:147-154.

Neufeld, K. N., Keinath, A. P., Gugino, B. K., McGrath, M. T., Sikora, E. J., Miller, S. A., Ivey, M. L., Langston, D. B., Dutta, B., Keever, T., Sims, A., and Ojiambo, P. S. 2018. Predicting the risk of cucurbit downy mildew in the eastern United States using an integrated aerobiological model. Int. J. Biometeorol. 62:655-668.

Ojiambo, P. S., Britton, W., and Keever, T. 2019. Annual epidemic histories. Cucurbit Downy Mildew Forecasting, http://cdm.ipmpipe.org/node/107.

Ojiambo, P. S., and Holmes, G. J. 2011. Spatiotemporal spread of cucurbit downy mildew in the eastern United States. Phytopathology 101:451-461.

Ojiambo, P. S., Paul, P. A., and Holmes, G. J. 2010. A quantitative review of fungicide efficacy for managing downy mildew in cucurbits. Phytopathology 100:1066-1076.

Olaya, G., Kuhn, P., Hert, A., Holmes, G., and Colucci, S. 2009. Fungicide resistance in cucurbit downy mildew. (Abstr.). Phytopathology 99:S171.

Quesada-Ocampo, L. M., Granke, L. L., Olsen, J., Gutting, H. C., Runge, F., Thines, M., Lebeda, A., and Hausbeck, M. K. 2012. The genetic structure of Pseudoperonospora cubensis populations. Plant Dis. 96:1459-1470.

Summers, C. F., Adair, N. L., Gent, D. H., McGrath, M. T., and Smart, C. D. 2015. Pseudoperonospora cubensis and $P$. humuli detection using speciesspecific probes and high definition melt curve analysis. Can. J. Plant Pathol. 37:315-330.

Thomas, A., Carbone, I., Choe, K., Quesada-Ocampo, L. M., and Ojiambo, P. S. 2017a. Resurgence of cucurbit downy mildew in the United States: Insights from comparative genomic analysis of Pseudoperonospora cubensis. Ecol. Evol. 7:6231-6246.

Thomas, A., Carbone, I., Cohen, Y., and Ojiambo, P. S. 2017b. Occurrence and distribution of mating types of Pseudoperonospora cubensis in the United States. Phytopathology 107:313-321.

Thomas, A., Carbone, I., Lebeda, A., and Ojiambo, P. S. 2017c. Virulence structure within populations of Pseudoperonospora cubensis in the United States. Phytopathology 107:777-785.

Thomas, A., Neufeld, K. N., Seebold, K. W., Braun, C. A., Schwarz, M. R., and Ojiambo, P. S. 2018. Resistance to fluopicolide and propamocarb and baseline sensitivity to ethaboxam among isolates of Pseudoperonospora cubensis from the eastern United States. Plant Dis. 102:1619-1626.

van den Bosch, F., Oliver, R., van den Berg, F., and Paveley, N. 2014. Governing principles can guide fungicide-resistance management tactics. Ann. Rev. Phytopathol. 52:175-195.

Wyenandt, C. A., Kline, W. L., and Ward, D. L. 2017. Effect of fungicide program on the development of downy mildew in three cucurbit crops in New Jersey. Plant Health Prog. 18:181-185. 